\title{
UNIVERSITYOF
}

FORWARD

THINKING

WESTMINSTER用

WestminsterResearch

http://www.westminster.ac.uk/westminsterresearch

\section{Being Well and Leading Well}

Illes, $\mathrm{K}$.

This is an accepted manuscript of an article published by Taylor \& Francis in Journal of Corporate Citizenship, Volume 2017, no. 68, pp. 15-30.

The final definitive version is available online:

https://dx.doi.org/10.9774/TandF.4700.2017.de.00004

(c) 2017 Taylor \& Francis

The WestminsterResearch online digital archive at the University of Westminster aims to make the research output of the University available to a wider audience. Copyright and Moral Rights remain with the authors and/or copyright owners.

Whilst further distribution of specific materials from within this archive is forbidden, you may freely distribute the URL of WestminsterResearch: ((http://westminsterresearch.wmin.ac.uk/).

In case of abuse or copyright appearing without permission e-mail repository@westminster.ac.uk 
Abstract

Purpose of the paper - The paper aims to raise awareness about the interconnected nature of leaders' wellbeing and the wellbeing of the organisations which they head. Leaders have a key role to play in recognising individual and collective responsibilities and showing the way towards a more human and healthier way of life. The benefits of connecting mind, heart and the felt sense are highlighted in the paper. It is argued that integrating practices of mindfulness and embodiment into the organisational culture can increase the levels of wellbeing, trust, honesty and the openness of communication.

Design/methodology/approach - This is a proposition paper based on a critical review of some aspects of the literature on leadership.

Findings - The paper provides evidence to support the interconnected nature of leaders' wellbeing and the wellbeing of their organisations. Development programmes are recommended to support not only the intellect but also the physical, emotional and spiritual wellbeing of individuals.

Research limitations/implications - This is a piece of secondary research and does not offer firsthand empirical evidence to support the findings.

Originality/value - This paper highlights the need to study individual and organisational wellbeing in a more multi-disciplinary and interconnected way.

Keywords - leadership development; wellbeing; Leadership Embodiment

Article type - Research Paper

\section{Introduction}

"The Earth is undergoing a period of intense techno-scientific transformation. If no remedy is found, the ecological disequilibrium this has generated will ultimately threaten the continuation of life on the planet's surface. Alongside these upheavals, human modes of life, both individual and collective, are progressively deteriorating" (Guattari, F. 2000, p. 17).

Guattari's striking statement is continuously validated by countless reports on the financial crisis, leadership scandals, wars, poverty and environmental disasters. Research in leadership, neurobiology, organisational and leadership development suggests that the socioeconomic, geopolitical and cultural-spiritual challenges of our time are interconnected (Guattari, F. 2000). The enormity of these social, environmental and mental challenges requires a review of how humans could relate to themselves, to each other and to the environment in a more responsible way (Obolensky, N. 2010). To address these issues we need a fundamental change of perspective. "Not only do we have to change things, but we have to change the way we see things" (Brabandere, L. de 2005 , p. xi). We need to let go of the mindset of maximum "me" - basically maximum personal material consumption - and start looking at the world as deeply interconnected (Scharmer, O. and Kaufer, K. 2013). Leaders have a key role to play in recognising individual and collective responsibilities and in showing the way towards a more human and healthier way of life. Learning to see beyond the familiar requires a particular kind of deep personal and collective listening. To recognise the patterns one needs to slow down, suspend judgement, listen with one's whole being, be comfortable with the silence and wait patiently for the feelings and thoughts to emerge. The challenge is to achieve this in a fast-paced world. 
This paper explores the possible connections between wellbeing and good leadership. Well-being is a concept that captures the important aspects of how people feel about and experience their daily lives - encompassing more than just physical health or economic indicators, well-being includes five elements: purpose, social, financial, community, and physical. (www.wellbeingindex.com)

This study is based on selected findings from multi-disciplinary sources and argues that the wellbeing of leaders and the wellbeing levels in the organisations they lead are interrelated.

\section{The Heavy Demands on Leaders}

Leaders are constantly in the spotlight and are often called upon to exercise authority without control. Indeed, contemporary economic and social change demands leadership by consent rather than by control. The phenomenon that is perceived as good leadership tends to be continuously cocreated by leaders and their followers, and is profoundly influenced by the purpose of the organisation and the context in which it exists; thus good leadership is a collective rather than an individual responsibility (Ladkin, D.2010.,Illes, K. and Mathews, M. 2015).

Trusted leaders are the guardians of the values of an organisation. They go far beyond the surface of race, ethnicity and gender, appreciate that people's internal characteristics are inferred from their observable qualities and so promote transparency (Eagly, A. H., Chin, J. L. A. and Norman, B. 2010). By supporting inclusivity they release the energy of people and enlarge the human and intellectual capital of the employees. In a trusting environment, one where members of the organisation are committed to a shared purpose they play active roles both as leaders and as followers. Authentic leaders know themselves and this helps them to be effective and moral (Walumbwa, F. O. et al. 2008) and lead by example.

There is general awareness about these complexities and the intense demands placed on leaders. The search for integrated and practical approaches to leadership and organisational development to support the wellbeing of leaders and followers in the workplace comes from many fields, including critical management studies (Sinclair, A. 2007; Ford, J. and Harding, N. 2007; Cunliffe, A. 2009; Alvesson, M. and Spicer, A. 2012), philosophy (Ladkin, D. 2010), business and virtue ethics (Zsolnai, L. 2015) and neuroscience (Hanson, R. 2009). Improving individual and organisational wellbeing requires long term commitment both from employees and institutions. Some organisations offer training programmes in emotional intelligence and mindfulness meditation, or encourage physical activity by supporting gym membership, while others introduce embodiment training and follow the techniques of Wendy Palmer (http://www.embodimentinternational.com), Paul Linden (http://www.being-in-movement.com)or Richard Strozzi-Heckler (http://www.strozziinstitute.com). Embodiment training focuses on the subjective aspect of the body. Participants on these training programmes pay particular attention to connecting the signals of the head, heart and the senses and learn to understand the environment and events more holistically. The ability to be fully present and listen with one's whole being is particularly important for leaders.

Ciulla (2011) calls for "good" leaders who are not only effective in the traditional sense of maximising value for shareholders, but who are also ethical and carefully consider the interests of all stakeholders and pay attention to the long-term impact of their decisions and the wellbeing of all. In essence, "good" in Ciulla's sense means reliable, trustworthy, sound, safe and effective. The good leader is expected to be fully present in the workplace, to be embodied and in touch with their higher purpose, emotionally intelligent, authentic, listen deeply, be prepared to show their weaknesses and ask for the support of others. Those leaders who meet these high expectations work for the common good and create strong communities, and although there are examples of embodied and morally sound leaders, there can be no doubt in the light of recent events that they are in the minority. Why is this so? 


\section{The Failings of Current Models}

There is growing evidence that rather than producing a sense of true wellbeing for people the materialistic model of mainstream business is failing and seriously undermining wellbeing. "Outmoded mental models have produced an intellectual bankruptcy: the bankruptcy of mainstream economic thought" (Scharmer, O. and Kaufer, K. 2013, p. 11). By advocating economic action on the basis of money-making, and by justifying success solely in terms of profits made, the materialistic business model encourages the irresponsible behaviour of economic actors, contributes to ecological destruction and disregards the interests of future generations. Buddhist economists (Brown, C.2017, Zsolnai, L. 2014) and Ecological economist (Jakobsen, O 2017.) challenge the fundamental ideas of free market economy and argue that human nature is not only greedy but also generous and altruistic even as it cares about itself so we need to make socially and morally responsible choices to protect the planet for future generations. The 2015 Edelman Trust Barometer indicated that people distrust change for change's sake: "By a two-to-one margin, respondents in all nations that took part in the survey feel the new developments in business are going too fast and there is not adequate testing. Even worse, 54\% say business growth or greed/money are the real impetuses behind innovation - that is two times more than those who say business innovates because of a desire to make the world a better place or improve people's life" (p. 2).

Current business models fail in other ways. Alvesson and Spicer (2012) suggest that organisations do not take advantage of the available knowledge of employees, and assert that what they term "functional stupidity" is an integral part of many workplaces: "Functional stupidity refers to an absence of reflexivity, a refusal to use intellectual capacities in other than myopic ways, and avoidance of justifications" (p. 1194). Asking difficult questions is not encouraged, and challenging the "way we do things around here" culture is frowned upon. Forms of stupidity management repress or marginalise doubt and block communicative action. Individuals are encouraged to focus on the positive and marginalise or dismiss more negative or critical ideas. One must concede that functional stupidity does create some certainty for individuals and organisations; however, at the same time it also creates a dissonance among many other individuals and organisations. When elements of functional stupidity are recognised and openly discussed in the organisation, a more humble attitude can be developed. Perhaps the stupidity that we see is "not due to an individual's cognitive deficiencies, but to active stupidity management" (Alvesson, M. and Spicer, A. 2012, p. 1216).

The presupposed and still widely used "rational management model" is, in fact, highly irrational and damaging if it produces non-rational outcomes for society, nature and future generations. There is a disconnect between reality and awareness, between an eco-system-centric global economy and an ego-centric awareness of institutional decision makers (Scharmer, O. and Kaufer, K. 2013). Yet despite what appears to be self-evident failings, the message does not seem to be getting through. A recent Chartered Management Institute (CMI) report (McBain, R. et al. 2012) suggests that organisations spend between $£ 1400$ and $£ 1700$ per annum per person on a manager's role and on leadership and management development programmes. Is this money well spent? It would appear not: Jan Hills found that sophisticated development programmes, many at high-ranking institutions, cost much more than the CMI's suggested figures but fail to produce changes in behaviour (Hills, J. 2013). According to Hills, the programmes are simply not compatible with how the brain learns and how behavioural change takes place. No one ever changed their behaviour because they learnt a new model, attended a lecture, or because the boss told them to change. That is just not how behavioural change happens. In fact, the neuroscience of learning and behaviour change is far more complex and multi layered.

Rath, T. and Harter, J. (2010) found that there are five essential elements to wellbeing. These are: Career wellbeing, Social wellbeing, Financial wellbeing, Physical wellbeing and Community 
wellbeing. The large scale study that they conducted in partnership with Gallup revealed that although $66 \%$ of people do well at least in one of these five areas only $7 \%$ thrive in all five areas. How can we improve our wellbeing individually and organisationally?

Based on clinical trials and case study evidences, Siegel claims "that creating well-being - in our mental life, in our close relationships and even in our bodies - is a learnable skill" (Siegel, D. 2011, p. xiv). According to Siegel's research wellbeing emerges when connections are created and separate elements of the brain are linked together into a working whole. Clearly, different approaches are required, something that has been recognised by theorists working in the field. Bruce Lipton's (2015) seminal book, The Biology of Belief explains how truly connected the mind, body and spirit are. It is now widely recognised that genes and DNA do not control our biology. Instead, they are controlled by signals from outside the cell, including energetic messages emanating from our thoughts. Lipton's research in cell biology and quantum physics puts the power to create a healthy, joyous life back in our own hands. Lipton argues that when we transform our conscious and subconscious thoughts, we transform our lives, and in the process help humanity to evolve to a new level of understanding. Management scholars suggests new ways of relating to others and developing in the workplace. Adler for example believes that " 21 st century organisations need to engage in new, more spontaneous, and more innovative ways of managing" (Adler, N. 2006, p. 486). She recommends using arts in leadership development to broaden individual and organisational perspectives through experiences, questions and reflection. Burgess (2008) calls for a deeper understanding of the stories of the past and recommends a focus on the future by living a legacy. A more holistic approach to learning is needed. The "Mantle of the Expert" method, for example, offers a "communication system that allows learning to take place simultaneously at conceptual, personal and social level" (Heathcote, D. and Phyl, H. 1985). But we do not have to look to contemporary thinkers for practical solutions to age-old problems.

\section{Lessons from History}

None of the problems outlined above are in any way new: the search for good leaders, the desire for personal and collective wellbeing, the search for meaning and how to live a good life have been with us throughout the ages. Indeed, the wisdom traditions give us clear guidance on how to live and lead well. Aristotle, for example, defines virtues as conscious habits that we have. We learn them through education and role models, and when we continuously practise them they become an integral part of who we are (Aristotle, Nichomachean ethics, Bk. 2.5). His ideas from 2,500 years ago resonate with the process of successful behavioural change that is posited by neuroscience (Siegel, D. 2011).

Leaders and followers can develop new habits (Ford and Harding, 2007) and stronger character by cultivating the inner and not only the outer self (Kiel, 2005). Kiel found that leaders fall into fall into two categories: Self-focused leaders, and leaders with strong moral character. Kiel defines character as an individual's unique combination of internalised belief and moral habits that motivate and shape how that individual relates to others.

There are four universal moral principles of integrity, responsibility, forgiveness and compassion that are demonstrated in a wide range of cultures. Strong character leads to the integrated self $-\mathrm{a}$ joining of head and heart, where thoughts, feelings and actions are in harmony, resulting in behaviour that demonstrates the character of an individual who walks the talk of his or her belief system. Our behaviour, especially as demonstrated through our relationships with others, is where our character comes to life.

In his book, The Return on Character, Kiel (2005) argues that leaders with strong moral character are recognised by their consistent actions. They keep promises and follow through on commitments (integrity habit). They Own up to mistakes (Responsibility habit) and accept that other people will 
also make mistakes (forgiveness). They treat people as people - showing interest in them and helping them to accomplish their personal goals and develop their skills (compassion).

To give a further historic example let us consider Confucius: "If a ruler sets himself right, he will be followed without his command. If he does not set himself right, even his commands will not be obeyed" (Confucius, Analects, 13.6). To "set oneself right" requires a commitment to selfknowledge and continuous character and personal development. According to Plato an "unexamined life" is not worth living, and a more modern philosopher, Kierkegaard, observed that "Life is not a problem to be solved, but a reality to be experienced." To experience reality, leaders and followers need to learn to be fully present and listen to the messages of the environment, their emotions and senses as well as their rational thoughts.

Confucius observes that "A man of humanity, wishing to establish his own character, also establishes the character of others, and wishing to be prominent himself, also helps others to be prominent" (Confucius, Analects, 6.28). In other words, if leaders put the emphasis on developing their own character it has a positive impact on the character and behaviour of others around them. By increasing their personal wellbeing they also have a positive impact on the wellbeing of the organisation.

Wellbeing is situated not only in individuals but also in organisations and communities. These aspects of wellbeing are interconnected and interdependent (Prilleltensky, I. and Prilleltensky, O. 2006).

In summary then, we can see that hugely disruptive events on a global scale are now forcing organisations to critically review how they operate and how they take part in shaping the future of the world's communities. It follows that new platforms need to be created to debate how to live, and what kind of legacy and planet to leave for future generations.

\section{A Relevant Methodology}

Changing perceptions is not easy, particularly in an environment where unchallenged assumptions about business are taken for granted.

"How do we change mentality? How do we reinvent social practices that would give back to humanity - if it ever had it - a sense of responsibility, not only for its own survival, but equally for the future of all life on the planet, for animal and vegetable species, likewise for incorporeal species such as music, the arts, cinema, the relation with time, love and compassion for others, the feeling of fusion at the heart of the cosmos" (Guattari, 2000, p. 71).

This paper calls for a broader critical review of the interrelated challenges in social, mental and environmental ecologies, and multi-disciplinary research in order to understand these complex issues. Deeply ingrained practices that are based on a fragmented and individualistic view of the world are becoming less and less sustainable and continue to cause untold damage. This is clearly an area where more conceptual and empirical research is urgently needed.

Researching in social science using only methodologies borrowed from natural sciences is no longer sufficient. Phenomenology provides a different way of perceiving reality. "Phenomenology examines the limitations of truth: the inescapable 'other sides' that keep things from ever being fully disclosed, the errors and vagueness that accompany evidence, and the sedimentation that makes it necessary for us always to remember again the things we already know" (Sokolowski, R. 2000 , p. 2). It reclaims the validity of epistemologies more associated with philosophy than science, especially in developing truths about the everyday world of human beings. Phenomenology recognises the subjective nature of knowledge and pays close attention to lived experience as a valid source of knowing. It embraces the significance of meaning within the human sense-making 
processes. Concerned with aspects of quality rather than quantity, it reasserts the importance of felt experience as well as the cumulative effects of history on our ability to know.

Edmund Husserl (1970) argued that the tools of modern science are not equipped to address questions of meaning and significance central to human lives. To better understand a phenomenon such as leadership, for example, it must be studied in the particular circumstances in which it arises rather than through abstract theoretical frameworks (Husserl, E. 1967). Phenomenologists argue that the way any perceived phenomenon is known is entirely interwoven with the viewpoint of the perceiver. Phenomenology offers a "universal framework for all of human endeavour", and as such encompasses scientific as well as philosophical dimensions.

Social construction is a unique human process. Freedom, for example, does not exist in a material form; it does not have substance or shape (Ladkin, D. 2010, p. 20). The power of concepts arises from the way in which they remain unquestioned and generally accepted. In order to change perceptions new questions need to be asked, and the interconnectedness of the different sides and aspects of the phenomenon need to be observed and appreciated.

From a phenomenological perspective, an entity's identity always remains elusive, and a thing's identity will always be beyond the reach of complete human appreciation. Certain phenomena such as leadership, management, creativity, business and wellbeing do not exist on their own. Their "beingness" is dependent on the things of which they are part of. Consequently, they cannot be removed from their environment and coldly studied in the abstract. A phenomenological perspective acknowledges the subjective nature and limitations of research in social science.

A more phenomenological approach in leadership research encourages us to review perceptions more comprehensively. Ciulla (2008, p. 393), for example, argues that "Leadership is a human phenomenon embedded in culture, which includes art, literature, religion, philosophy, language and generally all those things that constitute what it means to live as a human being."

Reinforcing the need for a different perspective, Ladkin states that "Leadership does not exist without people who are in some way identified as 'leaders' or people who are identified as people who they will lead. Neither can it exist outside of a particular community of organisational culture or history. For these reasons [Ladkin argues] rather than being a 'whole', leadership can best be described as a 'moment' of social relations" (Ladkin, D. 2010, p. 26).

\section{Being in the Present}

Changing perspectives is an individual process. It requires a level of curiosity, open-mindedness, continuous questioning and regular reflection. In confronting oneself, taking responsibility for one's own thoughts, feelings, emotions and actions, one touches upon a heightened level of awareness where unity can be experienced (Andras, L. 2015). When one slows down and spends time examining oneself it becomes possible to transcend the ego and create experiences of interconnectedness and wholeness (Hanson, R. 2009).

According to Scharmer (2009), when one listens deeply to the emerging needs of people in the workplace, for example, one is able to step into the most relevant and useful roles and make appropriate and valuable contributions both when leading and when following. Members of organisations with a deep level of listening trust themselves and each other. They build and nurture trusting relationships and allow the future to emerge organically. This supports the conceptualisation of leadership as a collective process - what may be described as Ladkin's "'moment' of social relations" (Ladkin, D. 2010, p. 26). When one wants to contribute to and 
participate in the continuously emerging "moments" of social relations, it is important to be fully present with all of one's faculties.

There are well-tested methods in the wisdom and spiritual traditions that offer effective ways for training the mind to be present and focus on the now rather than on the past or on the future. These traditions teach candidates to slow down, quiet the restive busyness of the mind, suspend judgement, let go of the past, be with the empty space within, accept the uncertainty of not knowing and patiently wait for something new to emerge.

Creating free space and allowing the future to emerge is a necessary condition for bringing forth creative, ethically sound ideas and practices. This process restores intrinsic motivation and provides a long-term horizon. There is evidence from throughout history to support the value of contemplation. Today, spiritual and reflective practices are starting to gain recognition in organisational and educational settings. However, both in academia and business, instrumental and utilitarian rationality are still the dominant perspective. It will be a challenge to shift this perspective towards a deeper, non-instrumental and non-utilitarian experience of life. Current forms of education provide plenty of opportunities for learning how to satisfy the hunger for money and material success. However, one needs to search carefully and select critically the appropriate guidance when it comes to searching for meaning and purpose in life (Illes, K. 2016). The interest in Mindfulness Meditation (Kabat-Zinn, J. 2011), Leadership Embodiment (Melina, L. R. et al. 2013) and the search for ethical, sustainable and spiritually inspired business (Bouckaert, L. and Zsolnai, L. 2012) indicate a shift in attitudes of seekers who want to live and work differently.

\section{Biology and Neuroscience}

"We do not think ourselves into new ways of living, we live ourselves into new ways of thinking" (Rohr, R. 1999).

In Western societies the emphasis tends to be on rational thinking, and there is a widely held belief that it is cognition that makes the ultimate decisions in life. "Cogito ergo sum" (I think, therefore I am (Descartes)) runs deeply in the collective subconscious of Western societies. That does not necessarily mean that this belief is consistently practised. "We live in a culture that privileges the rational mind, while tending to dismiss the somatic, emotional, and subconscious aspects of ourselves as irrelevant or counterproductive to intelligence. From a Western model, we feel we should have the mental fortitude to think our way out of stressful situations" (Palmer, W. 2013. pp 6-7).

When leaders (or followers) try to think themselves into new ways of living they often fail because the body is not invited or consulted about their intent. The emotions and the nervous system often sabotage the mind's rational plans. Over the past few years advances in biology and neuroscience have started to provide solid scientific evidence that shows that the body and the emotions have their own rationality. If one wants to make full use of one's faculties one needs to read the messages of one's senses and emotions and build stronger connections between the different parts of the brain (Siegel, D. J. 2009).

The human brain is a complex organ. To develop this discussion and to understand the dynamics of the brain under stress it is important to make a rough distinction between three areas of the brain: the neocortex, the limbic and the reptilian parts (Crawford, J. 2011).

- The neocortex is the newest part of the brain. It is responsible for higher level thinking, for example reasoning and future orientation. 
- The limbic system is the seat of emotions and memory. It is revealed in our relationship to others through three processes: resonance, regulation and revision (Lewis, T. et al. 2000). Limbic resonance shows how one attunes emotionally to others and gets a feel for their internal state. Limbic regulation is the ability of a person to influence the mood of others around them. Someone can walk into the room and their presence can have a calming effect, while others have the opposite effect on their environment. Limbic revision refers to the brain's capacity to rewire itself over time when exposed to a different emotional patterning. When one is surrounded by emotionally healthy people, one will become more stable emotionally over time. And when one is in a stressful environment for a long time one will become tenser unless there is a well-established practice for grounding oneself. The mirror neurones make one resonate physiologically with others. Even respiration, blood pressure and heart rate can rise and fall in sync with another's internal state (Siegel, D. 2011, pp. 61-65).

- The reptilian area of the brain is also called the brainstem. This is the oldest part of the brain and it regulates the automatic body functions such as breathing and heartbeat. This is the most primitive part of the brain, but the most crucial to human survival. It controls the fight, flight and freeze responses.

\section{Amygdala Hijack}

Within the limbic part of the brain there is a pair of structures called the amygdalae. They process the emotional intensity of incoming stimuli and decide which brain systems should be recruited to respond. The amygdala is also called the "fear centre" because of its central role in evaluating threat. Depending on the threat level the amygdala decides whether the higher brain (the neocortex) or the reptilian brain should deal with the stressor. The higher the perceived threat the more likely it is that the brain will default away from creative problem-solving and fall back on habitual responses from the past, or at worst choose a base level fight, flight or freeze response (Crawford, J. 2011). When the lower part of the brain takes over it is called the "amygdala hijack". In this state one focuses only on survival and safety. It is an "ego-centric" state and it is not possible to give others a sense of connection. One can, for example, freeze and respond with fright and a blank mind when the CEO asks an unexpected question. One fights and gets into an angry defensive state when challenged by someone. These are unconscious and involuntary processes, but the higher functions are often still all-too aware, and give one an excruciatingly frustrating experience when one is aware of what is happening but cannot stop it (Brack, A. 2015, pp. 80-81). After the event, when one regains balance, it is easy to know how one should have - or could have - responded if one had been in a relaxed and focused frame of mind.

Through applying embodiment techniques one can learn to recognise individual stress patterns, prevent or quickly recover from an amygdala hijack and learn to respond more skilfully in stressful situations.

\section{Leadership Embodiment}

Over the past thirty years researchers have been searching for a holistic approach to support the growth and development of individuals from physical, emotional and cognitive perspectives. In this paper we offer one example of such an integrated approach "Leadership Embodiment" (LE), which originated in the human potential movement.

The purpose of humanistic therapy (Cain, D. J. 2002; Schneider, K. J., Pierson, J. F. and Bugental, J. F. 2014; Young, M. 2014; and Barber, P. 2012) is to allow a person to make full use of his or her personal capacities, in the process leading to self-actualisation. Self-actualisation requires the integration of all the components of one's unique personality. These elements or components of personality include the physical, emotional, intellectual, behavioural and spiritual. The marks of a 
self-actualised person are maturity, self-awareness and authenticity. Humanistic therapists think that most people - not only those with obvious problems - can benefit from opportunities for selfdevelopment.

According to Palmer (2013), LE is built on the wisdom of Aikido, the non-aggressive martial art, mindfulness, meditation and findings in neuroscience. This approach is practical and teaches how the posture, the way one sits or stands can change the way one thinks or speaks. It develops centred, powerful leadership by teaching how to develop a mindful interest in the situation and how to shift from reactive reflexes to responsive choices.

LE focuses on changing habitual, less conscious behaviour and developing more skilful responses in challenging and stressful situations. Leaders are invited to be open-minded and discover their habits, show an interest in their own and other people's patterns and maintain a mindful interest towards all individuals and situations.

"Mindful interest means that there is openness to examining problems and the possible remedies while relating to a continual stream of discovery. This type of openness is the hallmark of a great leader and includes the practice of dropping the defensive mask of self-protection and allowing oneself to be transparent and accessible as a human being - one who wants to work with, rather than control others" (Palmer, W. 2013, p. 1).

According to Palmer, outstanding leaders have three competencies:

1 Inclusiveness: they are able to expand their presence and "embrace" even large audiences by creating a "we are all in this together" feeling.

2 Centred listening: they listen with their whole being, and hear all what is being said without taking the message personally.

3 Speaking up: they are able to speak their truth (even when it is not a popular view) with clarity and precision and without becoming aggressive or collapsing.

LE developed a set of practical exercises to help individuals to develop, and through daily repetition, master inclusiveness, centred listening and speaking up. LE practice uses mild physical pressure and simulates stress to observe the body's reactive, survival pattern. Then, while the pressure is still on, leaders learn to shift to a more uplifted, open and relaxed way of being. Over time they develop a strong awareness about the interconnectedness of body posture and the production of testosterone, cortisol and oxytocin in the body. Power Posing (Cuddy, A. et al. 2012) gives immediate feedback of the changes one can achieve in the body within a relatively short time. When leaders (and followers) work with their patterns, focus on their posture, the quality of breathing and regularly return to a centred state even during a busy day, they notice the increase in energy levels and the positive impact that it has on personal wellbeing and the wellbeing of others around them.

\section{Conclusion}

In this proposition paper possible connections between the individual's level of wellbeing and his/her ability to lead well in stressful and complex environments were explored. It appears that there are supportive evidences to this proposition both in the leadership development and the wellbeing literature. How well one is has an impact on what one can achieve in the workplace and beyond. Although an individual's wellbeing is primarily a personal responsibility, it is also a collective and organisational duty to reduce the levels of stress and eliminate toxic work environments where "functional stupidity" prevents individual growth and undermines creativity and productivity. 
It seems clear that leaders would benefit from paying more attention to their physical and emotional wellbeing. In order to face the growing demands that are being placed upon them, leaders need to be able to utilise the signals of the limbic system and the reptilian brain, and learn to incorporate their feelings and the information of the senses into their rational decision-making processes. It requires an ongoing commitment to learning from the wisdom traditions and from neuroscience, finding time for silence and giving equal attention to the needs of the body, heart, soul and intellect.

Further research is needed to test the propositions of this paper. Empirical evidence could highlight the benefits of a more integrated leadership development programme to individuals, communities and society. A longitudinal study of at least one year is proposed when participants would learn and regularly practice paying attention to their inner worlds. Such a study would give both participants and researchers an opportunity to observe and record the changes in attitudes, behaviours and habits both in individuals and in the organisational culture. Anecdotal evidence certainly suggests that paying attention to the "interior condition" is important.

Bill O'Brien, the CEO of Hanover Insurance, spoke from personal experience when he noted: "the success of an intervention depends on the interior condition of the intervener" (Quoted in Scharmer, O. 2008). What counts, is not only what leaders do and how they do it, but the "interior condition", the inner place from which they operate. Understanding and nurturing this inner place is key to the wellbeing of all human beings, and it appears to be an absolutely fundamental prerequisite of a leader's wellbeing and of good leadership itself.

\section{References}

Adler, N. (2006), “The arts \& leadership: Now that we can do anything, what will we do?”, Academy of Management Learning \& Education, Vol. 5 No. 4, pp. 486-499.

Alvesson, M. (2012), "Critical leadership studies: The case for critical performativity, human relations", Vol. 65No. 3,pp. 367-390.

Alvesson, M. and Spicer, A . (2012), "A stupidity-based theory of organisations", Journal of Management Studies, Vol. 49 No. 7, pp. 1194-1220

Andras, L. (2015), "The forgotten half of sustainability and leadership: The inner perspective - The Sufi approach", in Zsolnai, L.. (Ed.), The Spiritual Dimension of Business Ethics and Sustainability Management, Springer, pp. 37-46

Aristotle (1985), Nichomachean Ethics, Indianapolis, Ind. : Hackett Pub. Co.,

Barber, P. (2012), "Emergent coaching - A gestalt approach to mindful leadership", Coaching Review, Vol. 1 No. 4 (Tradycje teoretyczne-modele praktyczne-modelowe praktyki), pp. 29-40.

Bolden, R. et al. (2011), Exploring Leadership, Oxford University Press, Oxford.

Bouckaert, L. and Zsolnai, L. (2012), "Spirituality and business: An interdisciplinary overview", Society and Economy, Vol. 34 No. 3, pp. 489-514.

Brabandere, L. de (2005), The Forgotten Half of Change - Achieving Greater Creativity through Changes in Perception, Dearborn Trade Publishing, Chicago, IL. 
Brack, A. (2015), "Application of embodiment in organisations: Benefits to leadership, communication and innovation”, The Embodiment Journal, Vol. 1, pp. 76-96.

Brown, C. (2017) Buddhist Economics, Bloomsbury Press, New York

Burgess, G. J. (2013), "Leadership Thresholds", in Melina, L. R. et al. (Eds.) The Embodiment of Leadership, Jossey-Bass Publishing,

Burgess, G. J. (2008) Dare to Wear Your Soul on the Outside: Live Your Legacy Now Jossey Bass Publishing

Cain, D. J. (2002), Humanistic Psychotherapies: Handbook of Research and Practice, American Psychological Association,

Ciulla, J. B. (2011), "Ethics and effectiveness: The nature of good leadership", in Annotates, J. and Day, D. (Eds.), The Nature of Leadership, $2^{\text {nd }}$ edn, Sage, Thousand Oaks, pp. 508-540.

Ciulla, J. B. (2008), “Leadership studies and the 'fusion of horizons'”, Leadership Quarterly, Vol. 19 No. 4, pp. 393-395.

Confucius (1969), Analects, in Wing-Tsit Chan (ed.), A Source Book on Chinese Philosophy: Selections from the Analects, Princeton University Press, Princeton, NJ, pp. 14-49.

Crawford, J. (2011), The Brain-Friendly Organisation: What Leadership Needs to Know for Intelligence to Flourish http//:www.cascadance.com/wpcontent/uploads/2011/04/Crawford.BrainFriendly-Organization.Article.Formatted.rev082911.pdf

Cuddy, A. J. et al. (2012), “The Benefit of Power Posing Before a High-Stakes Social Evaluation”, working paper No. 13-027, Harvard Business School.

Cunliffe, A. (2009), "The philosopher leader: On relationalism, ethics and reflexivity - A critical perspective to teaching leadership", Management Learning, Vol. 40 No. 1, pp. 87-101.

Eagly, A. H. et al. (2010), "Are memberships in race, ethnicity, and gender categories merely surface characteristics?”, American Psychologist, Vol. 65 No. 9, pp. 934-935.

Edelman Trust Barometer 2015, Executive Summary p. 2.

Ford, J. and Harding, N. (2007), "Move over management, we are all leaders now", Management Learning, Vol. 38 No. 5, pp. 475-493.

Grint, K. (2005), Leadership: Limits and Possibilities, Palgrave Macmillan, Basingstoke.

Guattari, F. (2000), Three Ecologies, The Athlone Press, London and New Jersey

Hanson, R. and Mendius, R. (2009), Buddha's Brain, The Practical Neuroscience of Happiness, Love and Wisdom, New Harbinger Publications Inc.

Heathcote, D. and Phyl, H. (1985), "A drama in learning: Mantle of the expert", Theory into Practice, Vol. 24 No. 3, pp. 173-180.

Hills, J. (2013), Leadership Development is not Working. Here is why http://www.hrzone.com/talent/development/leadership-development-is-not-working-heres-why 
Husserl, E. (1970), The Crisis of European Science and Transcendental Phenomenology, translated by Carr, D., Northwestern University Press, Evanston, IL.

Husserl, E. (1967), Cartesian Meditations, translated by Cains, D., Nijhoff, The Hague.

Illes, K. and Zsolnai, L. (2015a), “The role of spirituality in business education”, Society and Business Review, Vol. 10 No. 1, pp. 67-75.

Illes, K. and Mathews, M. (2015b), "Leadership, trust and communication”, paper presented at the Institute of Internal Communication Conference, 27 February 2015, Leicester. http://www.top-b.com/trustinleadership

Illes, K. (2016), "Connectedness and spirituality: A Christian and Hindu example of spiritual based entrepreneurship", in Chatterji, M. and Zsolnai, L. Ed Ethical Leadership: Indian and European Spiritual Approaches, Palgrave-Macmillan

Jacobsen, O. (2017) Transformative Ecological Economics; process Philosophy, Idealogy and Utopia, Routledge, Oxon, UK

Kiel, F. (2015) Return on Character, Harvard Business Review Press, Boston, USA.

Kabat-Zinn, J. (2011), Wherever You Go, There You Are, Piatkus Publishing

Ladkin, D. (2010), Rethinking Leadership, Edward Elgar Publishing

Levine, P. (2008), Healing Trauma, Boulder, CO.

Lewis, T. et al. (2000), A General Theory of Love, Random House Publishing

McBain, R. et al. (2012), The Business Benefits of Management and Leadership Development, Chartered Institute of Management, London.

Medical Dictionary: http://medical-dictionary.thefreedictionary.com/Human-Potential+Movement

Melina, L. R. et al. (Eds.) (2013), The Embodiment of Leadership, Jossey-Bass Publishing,

Moberg, D. O. (2002), “Assessing and measuring spirituality: Confronting dilemmas of universal and particular evaluative criteria”, Journal of Adult Development, Vol. 9, pp. 47-60.

Muldoon, M. and King, N. (1995), "Spirituality, health care, and bioethics", Journal of Religion and Health, Vol. 34, pp. 329-349.

Obolensky, N. (2010), Complex Adaptive Leadership, Gower Publishing Limited

Palmer, W. and Crawford, J. (2013), Leadership Embodiment, CreateSpace Publishing,

Palmer, W. and Palmer, T. (2014), Leadership Embodiment Coach Training Manual, manuscript

Prilleltensky, I. and Prilleltensky, O. (2006) Promoting Well-being: Linking Personal, Organisational and Community Change, John Wiley and Sons Inc. New Yersey 
Rath, T. and Harter, J. (2010) Well-being: The Five essential elelments, Gallup Press, New York, 2010

Rohr, R. (1999), Everything Belongs, Crossroad Publishing Company

Scharmer, O. (2008), "Uncovering the blind spot of leadership", Leader to Leader Institute, No. 47, pp. 52-59.

Scharmer, O. (2009), Theory U: Leading from the Future as it Emerges, Berrett-Koehler Publishers, Inc., San Francisco, CA.

Scharmer, O. and Kaufer, K. (2013), Leading from the Emerging Future, Berrett-Koehler Publishers, Inc., San Francisco, CA.

Schneider, K. J. et al. (Eds.) (2014), The Handbook of Humanistic Psychology: Theory, Research, and Practice, Sage Publications

Siegel, D. J. (2011), Mindsight: Transform your Brain with the new Science of Kindness, Oneworld Publications, London.

Siegel, D. J. (2009), "Mindful Awareness, Mindsight, and Neural Integration", The Humanistic Psychologist, Vol. 37 No. 2, pp. 137-158.

Sinclair, A. (2007a), "Teaching Leadership Critically to MBAs", Management Learning, Vol. 28 No. 4, pp. 458-472.

Sinclair, A. (2007b), Leadership for the disillusioned: Moving beyond myths and heroes to leading that liberates, Crows Nest, Australia, Allen and Unwin.

Sokolowski, R. (2000), Introduction to Phenomenology, Cambridge University Press, Cambridge.

Spillane, J. (2004), Distributed Leadership: What's all the hoopla? Institute for Policy Research, Northestern University

Strozzi-Heckler, R. (2014), The Art of Somatic Coaching, Embodying Skilful Action, Wisdom, and Compassion, North Atlantic Books

Walumbwa, F. O. et al. (2008), "Authentic leadership: Development and validation of a theory based measure", Journal of Management, Vol. 34 No. 1, pp. 89-126.

Young, M. (2014), "Leadership that develops other people: An empirical study into the effect of humanist principles and therapeutic common factors on subordinate development", Journal of General Management, Vol. 39 No. 3, pp. 59-76.

Zsolnai, L. (2014) Beyond Self: Ethical and Spiritual Dimensions of Economics, Peter Lang, Oxford 